\title{
Carcinoma of the Lacrimal Gland cM0 TNM Finding v7
}

National Cancer Institute

\section{Source}

National Cancer Institute. Carcinoma of the Lacrimal Gland cMO TNM Finding v7. NCI

Thesaurus. Code C88806.

Carcinoma of the lacrimal gland without evidence of distant metastasis. (from AJCC 7th Ed.) 